\title{
Transitando entre Folhas e Bytes a Expressão da Mídia Impressa e da Mídia Digital na Cultura e na Produção de Subjetividades
}

Transiting between sheets and bytes the expression of the printed and digital media in the cultures and the subjectivity production

\begin{abstract}
Resumo: A comunicação pode ser entendida através de diversos dispositivos. Neste trabalho, optou-se pela escrita. Esta bifurca-se devido às transformações tecnológicas e culturais: a permanência dos meios de comunicação impressos juntamente à escrita digital. A partir disso, é possível analisar a sua coexistência como também a relação desses modos de comunicação com a cultura e os processos de subjetivação. Propõe-se pensar a mídia e os sistemas de comunicação inseparáveis da cultura a partir de um enfoque genealógico. Nesse sentido, percebe-se a processualidade dos agentes sociais de diferentes épocas. Para tanto, o trabalho tem a proposta da "tecelagem", onde vários autores, como Marshall McLuhan, Pierre Lévy, Félix Guattari, Neil Postman, André Lemos e Celso Cândido contribuem com diferentes “fios”, propondo, portanto, um entendimento transdisciplinar da relação entre cultura, mídia e subjetividade. Palavras-Chave: Psicologia Social, cibercultura, cultura, Comunicação Social.
\end{abstract}

\begin{abstract}
Communication can be understood through several 'dispositives' or modes of communication. For this study, writing was chosen as the mode of communication. It bifurcates-due to technological and cultural transformations - into the existence of printed media and digital writing. From this point of view, it is possible to analyze the coexistence of printed media and digital writing. It is also possible to analyze the relation of these media to culture and subjectification. Starting from a genealogical focus, the study proposes that media and communication systems cannot be understood apart from culture. In this sense, it is possible to perceive the processuality of the social agents in different time periods. Therefore, the study has a "weaving" character, where some authors like Marshall Mc Luhan, Pierre Lévy, Félix Guattari, Neil Postman, André Lemos and Celso Cândido contribute with various "threads", suggesting a multidisciplinary understanding of the relationship among culture, media and subjectivity.
\end{abstract}

Key Words: Social Psychology, cyberculture, culture, Social Communication.

Cristina Wulfhorst

Estudante de Psicologia ( ${ }^{\circ}$ semestre) $d a$ Universidade do Vale do Rio dos Sinos (UNISINOS)

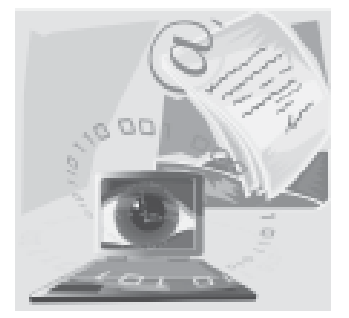

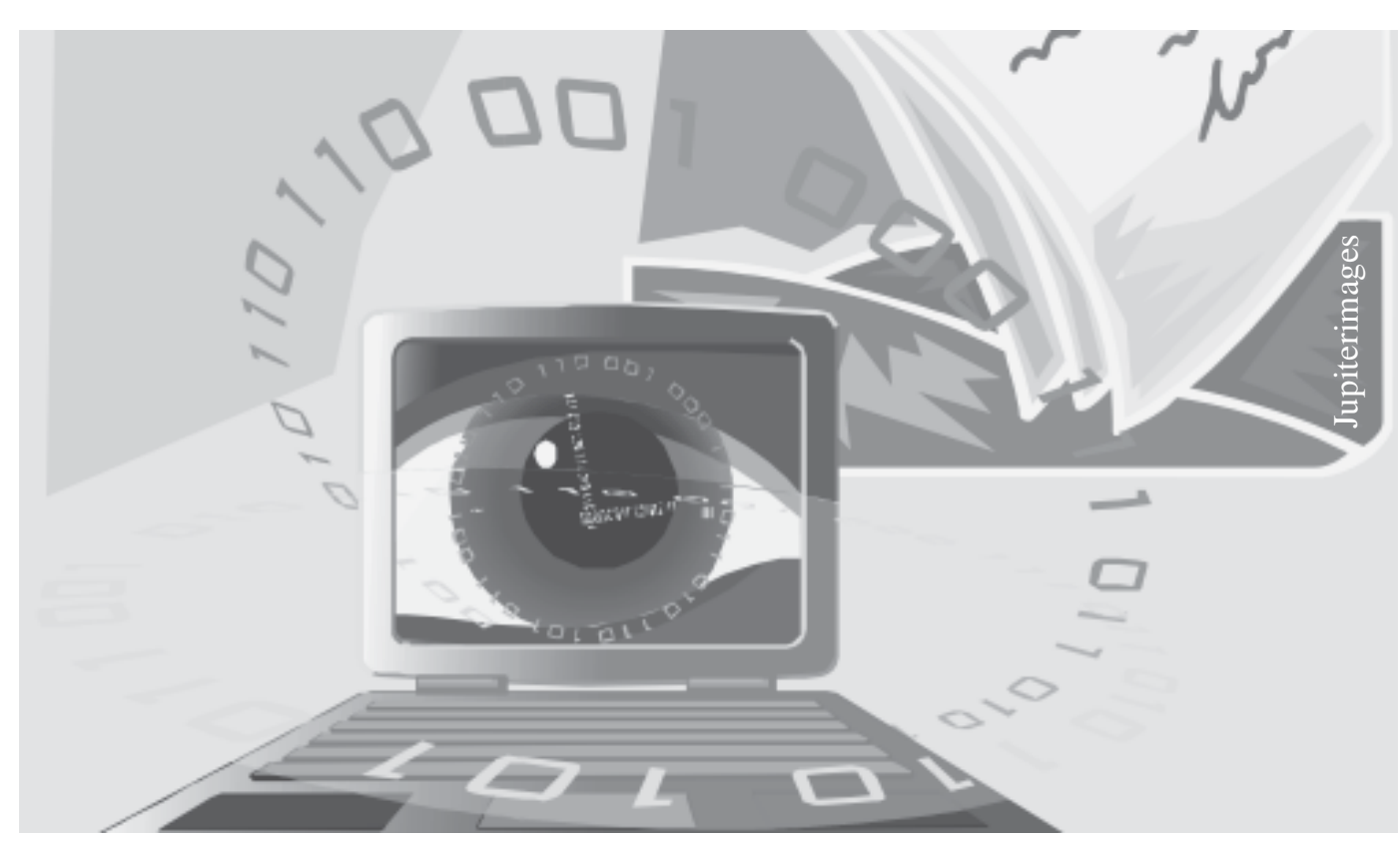


Sendo este trabalho uma referência ao professor Dante Moreira Leite, não faria sentido apenas um olhar sobre qualquer fenômeno, sendo que ele visava uma concepção não fragmentada do sujeito. Tinha a transdisciplinaridade "tecida nele".

Sendo assim, parto da idéia da tecelagem utilizando alguns fios para compor uma figura. Ao ser terminada, necessita de um olhar caleidoscópico. Nesse sentido, apresenta-se um entrecruzamento entre diferentes fios, representados pela Comunicação, Psicologia e Antropologia, a fim de refletir sobre os processos de subjetivação e construções culturais potencializadas pela comunicação. Os autores vêm desses diferentes campos, como Marshall McLuhan, Pierre Lévy, Félix Guattari, Neil Postman, André Lemos e Celso Cândido. Além disso, um enfoque genealógico, de historicidade, passa a ser relevante quando se pretende não apenas expor fatos mas também contextualizá-los.

A comunicação pode ser entendida através de diversos dispositivos. Neste trabalho, optou-se pela escrita. Esta será “tecida” pela análise da mídia impressa e digital. Parte-se, ainda, do pressuposto que a escrita é uma tecnologia indelevelmente ruptora e potencializadora, que, segundo McLuhan (1969), é uma extensão de nossos sentidos, alterando nossas percepções.

\section{Comunicação Social e Psicologia}

A Comunicação Social compreende todas as formas de produção simbólica, seu intercâmbio $e$ conservação entre os homens; parte da cultura, a consideração dos aspectos estruturais da Comunicação Social permite demonstrar sua complexidade [...] é parte do processo de produção e intercâmbio cultural, parte da dinâmica social, na qual se combinam sistemas de intercâmbio simbólico com a intervenção de tecnologias que ampliam o potencial humano para o intercâmbio (Santoro, 1986, p. 471).

Pensar em Comunicação Social nos faz pensar na Psicologia, nos processos de subjetivação em relação à comunicação. Como afirma Santoro (1986), o estudo da Comunicação excede os limites de qualquer disciplina. Os conhecimentos imbricam-se, tecem-se; não se sabe onde começa um e termina outro, sendo, portanto, híbridos ${ }^{1}$.

Santoro entende a Comunicação Social muito além da concepção de comunicação de massa: "Comunicação Social cobre todos os processos de geração, transformação, armazenamento e difusão de conteúdos simbólicos" (Santoro, 1986, p. 417), e considera que toda comunicação é, por definição, social.
Assim, os próprios meios² já são informação, condicionantes de mudança (McLuhan, 1969). A escrita é considerada um meio, logo, é uma faceta da Comunicação Social.

\section{Conceitos de Cultura}

A difusão do saber e o desenvolvimento da comunicação entre os homens conseguirão um dia lhes fazer em harmonia, na aceitação e no respeito de sua diversidade (Lévy Strauss apud Laraia, 2002, p. 37).

Para fazer a relação dos meios de comunicação com a cultura, faz-se necessário um breve panorama sobre conceitos de cultura e de suas transformações, sendo que, na medida em que o ser humano vai-se repensando, ele também reconstrói seus pontos de vista e conceitos.

O substantivo "cultura” significa, em seu uso primeiro, cultura agrícola, plantação e cuidados requeridos pelo cultivo. Depois de o sentido da cultura ter sido atrelado a esse uso mais concreto, ele é transposto para a esfera humana e passa a significar a "cultura do espírito", designando a formação intelectual do ser humano.

O conceito passou por várias visões, desde as positivistas do evolucionismo, o estruturalismo e relativismo cultural, até as considerações contemporâneas.

Com Charles Darwin e o positivismo (Semprini, 1999), cria-se a tendência de ver a cultura sob um aspecto evolucionista, de uma ordem histórica e de progressividade. Entende-se a seleção natural das culturas como a seleção natural das espécies, ignorando, assim, a variedade e riqueza peculiar das culturas. Alguns antropólogos, como Margaret Mead (1970), começam a preocupar-se com o estudo de culturas mais "primitivas" no sentido de mostrar as diferenças culturais a partir da vivência direta com os povos estudados. Houve, nesse processo, uma passagem de entendimento de "Cultura" para o plural "Culturas", a fim de romper com todo e qualquer padrão elitista e hierárquico.

O plural é a marca do discurso antropológico moderno, que tem como representantes Franz Boas e Durkheim (Laraia, 2002) no século passado. Tal discurso passa a ser alternativo àquele da época das grandes navegações e descobertas, dotado de uma visão colonialista eurocêntrica. Assim, abrese espaço para o particularismo histórico como reação à concepção evolucionista, enfatizando as especificidades das culturas. Continuando esse processo, há uma reorientação do particularismo histórico, com uma concepção relativista da cultura: o estruturalismo. Este tem Lévy Strauss
[...] as características psicológicas não poderão ser entendidas como fonte de desenvolvimento histórico e social. Ao contrário, as condições da vida social é que determinam as características psicológicas, embora estas, depois, passem também a influir na vida social. E ainda aqui será preciso distinguir?

Leite

10 conceito de hibridação é definido por Canclini como os "procesos socio-culturais en los que estructuran praticas discretas, que existían en forma separada, se combinam para generar nuevas estructuras. objetos e prácticas" (Canclini, 2001, p.14), e refere, ainda, o conceito, aos " $[$...] productos de las tecnologias avanzadas $y$ procesos sociales modernos $e$ posmodernos"(Canclini, 2001, p.22).

2 McLuhan considera os conteúdos dos meios secundários, sendo que "as sociedades sempre foram moldadas mais pela natureza dos meios do que pelo conteúdo da comunicação" (McLuhan, 1969, p. 30) 
(Auge, 1988) como representante, supondo que o progresso só seja possível na coalizão e relação entre as culturas, introduzindo a importância dos encontros interculturais.

Porém, os conceitos de cultura contemporâneos consideram os processos de subjetivação muito mais que o armazenamento, transmissão do conhecimento e manifestações a partir da estabilidade e identidade fixa.

Guattari (1992), a respeito disso, afirma que o conceito de cultura é profundamente reacionário, "pois separa atividades semióticas em esferas, padronizadas e capitalizadas para o modo de semiotização dominante, cortadas de suas realidades políticas” (Guattari, 2000, p.15). Williams (2002) apresenta outro conceito interessante, que considera a cultura sempre criativa, rompendo com a idéia de uma cultura elitista e outra popular: "a cultura é algo usual, originário: esse é o fato primordial. Toda sociedade tem sua própria forma, propósitos e sentidos” (Williams, apud Laraia, 2002, p.54).

Esses conceitos mais contemporâneos foram mudando com os meios de comunicação e tecnologias, sendo que estes revelam novos sentidos, como afirma Williams (2002): “Uma cultura possui dois aspectos: os sentidos e direções conhecidos (...) e as novas observações e sentidos, que são oferecidos e testados” (Williams, apud Laraia, 2002, p.54). Os meios de comunicação digitais permitem uma visão inédita, remetendo a uma a-historicidade, na qual as gerações já não perpassam, de maneira tão significativa, seus conhecimentos; a tecnologia tem um forte papel nesse sentido, onde, por exemplo, os mais novos estão ensinando os mais velhos. Não é à toa que os conceitos formulados para a cultura ficaram retrógrados em poucos anos. A tecnologia passa a idéia de re-invenção e ressignificação da cultura, e não uma idéia estagnada, como conceitos anteriores. Portanto, entende-se a mídia como forma de significação cultural.

\section{Cultura na Midia, a Midia na Cultura}

4 Autores como McLuhan (1969), Postman (1994) e Lemos (2002) utilizam o exemplo do relógio mecânico como uma tecnologia com forte ruptura paradigmática, uma vez que este passou a ser um meio de regular a vida privada dos cidadãos, além de marcar a passagem de uma lógica do público para a lógica do privado.
Comunicar é pôr em comum, entrar em relação. Nesse sentido, o desenvolvimento da mídia contemporânea, acompanhada pela transformação das culturas, das identidades, das formas de poder e da autoridade, gera novas formas de estar junto (Bougnox, 1993, p. 6).

A cultura produz a mídia e a mídia produz a cultura. Não há uma lógica cartesiana de causa, e, sim, uma simultaneidade e complementaridade. A mídia não deve ser entendida como algo "separado", "que vem de fora”, das quais somos as conseqüências.
O Diagrama de Foucault explica esse movimento, onde a constituição e a compreensão do sujeito não são dicotômicas, no sentido de algo estar "fora" e exigir adaptação. Deleuze (1988) desconstrói o entendimento fragmentado no momento em que considera sermos uma dobra desse fora, uma entre inúmeras possibilidades de ser. Já Postman (1994) posiciona a tecnologia da informação como algo externo, um "ser" invisível, autônomo, que atua sobre nossas vidas no momento em que afirma que "(...) o gênio que saiu da garrafa proclamou que a informação seria o novo deus da cultura e não avisou sobre os perigos do excesso de informação” (Postman, 1994, p.69).

Porém, ao retomarmos a idéia de Deleuze e Guattari, também nos colocamos como agentes e responsáveis pelos processos. Não se trata mais de receptor-emissor, da lógica da comunicação a partir da metáfora do tubo (Maturana; Varela, 1987). Há sempre uma ambigüidade numa interação comunicativa.

Segundo Cândido (2000), hoje nós compreendemos e interpretamos o mundo a partir do que vemos, ouvimos e lemos nos meios de comunicação, sendo que muito da formação subjetiva é, em grande parte, elaborada nesses processos de comunicação e informação. A mudança da escrita, de uma "passagem" do sentido do papel para os bytes, mostra o quanto as mudanças, os processos de subjetivação, são reordenados a partir da transformação das percepções pela tecnologia, uma vez que nossos sentidos são extensões das tecnologias. Antigamente, eram extensões mecânicas; hoje, a extensão é do nosso sistema nervoso central (McLuhan,1964).

Postman (1994) e Lévy (1995) usam o mesmo exemplo para se referir às mudanças em relação às tecnologias: o relógio mecânico do século $\mathrm{XVI}^{4}$. Porém, o primeiro autor o vê como determinante, o segundo, como condicionante, sendo que o que ocorre são condições para o favorecimento de tal atuação.

Com isso, esclarece-se que a mídia não é simplesmente uma representação exterior do mundo humano e seu cotidiano (...) são extensões das habilidades intelectuais e comunicativas humanas, constituindo, revelando, inventando parte importante do mundo dos desejos, das representações e do imaginário contemporâneo (Cândido, 2000, s.p.).

Porém, alguns autores, como Lipovetsky (1983), afirmam estarmos vivendo numa Era do Vazio, herança dos "tempos modernos" e de suas extensões mecânicas: o ser humano passou a ser 
Transitando entre Folhas e Bytes

a Expressão da Mídia Impressa e da Mídia Digital na Cultura e na Produção de Subjetividades

fragmentado, pulverizado. O efeito zapping poderia ser uma expressão disso. Facilitou-se a informação fragmentada. Se a leitura de um livro, a linearidade, tornou-se maçante para muitas pessoas, é porque algo foi afetado na sua subjetividade e é com isso e a partir disso que os indivíduos vão construindo cultura.

\section{A Midia Impressa e sua Revolução}

[...] as boas maneiras de ler hoje, é chegar a tratar um livro como se escuta um disco, como se olha um filme ou um programa de televisão, como se é tocado por uma canção; todo tratamento do livro que exigisse um respeito especial, uma atenção de outra espécie, vem de uma outra era e condena definitivamente o livro. Não há nenhuma questão de dificuldade nem de compreensão: os conceitos são exatamente como sons, cores ou imagens, são intensidades que convêm a você ou não, que passam ou não passam (Deleuze, 1988, p.10).

Com a invenção da escrita e, em seguida, dos meios de reprodução de texto, um novo suporte midiático é instituído, e, com ele, novas possibilidades de relações sociais. O texto impresso permite uma outra percepção e apropriação de saberes impensáveis nas sociedades orais. Uma idéia não precisa mais de uma retórica para ser transmitida e conhecida, e, pela primeira vez, os discursos podem ser separados das circunstâncias particulares em que foram produzidos. A memória e a inteligência não precisam mais encarnar em uma entidade viva.

A escrita foi o meio fundamental de comunicação e subjetivação das sociedades até o século XIX. Ela consolidou valores, critérios, materializou a informação, facilitando a impressão do "universal". Campos (1994) analisa a importância e longevidade dos livros. Afirma que o livro é o meio de comunicação mais antigo, data cerca de 6 mil anos. Desde o suporte de barro, passando por diversas transformações, manteve-se como um porta-voz do silencioso pensamento humano. Enfatiza-se a palavra "silencioso", que atualmente parece não ter muito reconhecimento, senão interpretado pejorativamente. Que valor nossa cultura dá, afinal, ao silêncio?! A televisão e outros meios sonoros preenchem os espaços vazios do silêncio e das entrelinhas.

Segundo Cândido (2000), a televisão excitou ao máximo as faculdades auditivas e televisivas do corpo, de tal modo que os outros sentidos, como a sensibilidade tátil e olfativa, são neutralizados. Passa-se a compreender o mundo com essas duas faculdades superexcitadas; literalmente, vemos e ouvimos o mundo. A neutralização dos sentidos, para McLuhan (1969), relaciona-se com a extensão de sentidos pelas tecnologias. Qualquer invenção ou tecnologia é uma extensão ou auto-amputação de nosso corpo, e essa extensão exige novas relações e equilíbrios entre os demais órgãos e extensões do nosso corpo.

Svend Dahl coloca a questão da transitoriedade típica dos nossos tempos: "o livro continuará com a vantagem de não ser passageiro como os demais meios de comunicação, mas um perdurável depósito de pensamentos e saberes da humanidade, sempre disposto a abrir-se de novo" (Dahl, apud Campos,1994, p.215). Assim, remetemo-nos à relativização do tempo, ou seja, o tempo para ler um livro é de fato um investimento, mas para baixar um programa para ler um texto não se pode esperar mais do que um minuto sem uma certa irritação e sensação de "perda de tempo”. Há menos tempo e paciência para o ato de ler, saborear um livro completo. O tempo que se precisa para pensar no que a leitura afetou, no que desestabilizou, concorre com o tempo sempre escasso. Anestesiaram-se o silêncio, as invenções, nas entrelinhas. Estas são sensações ligadas ao nosso fazer com a tecnologia.

De acordo com McLuhan (1964), durante as idades mecânicas, da qual a Era de Gutenberg faz parte, projetamos nossos corpos no espaço. A imprensa seria uma extensão do visual - a valorização do que pode ser visto. Para o autor, qualquer extensão afeta todo o complexo psíquico e social (McLuhan, 1964).

A imprensa, por exemplo, acentuou o individualismo e nacionalismo do século XVI. Esta, segundo McLuhan, tem um efeito duplicador, confirmou e prolongou a nova tensão visual: "psicologicamente, o livro impresso, como extensão da faculdade visual, intensificou a perspectiva e o ponto de vista fixo. A nova intensidade da pressão visual e do ponto de vista particular" (McLuhan,1964, p.142). A imprensa forneceu a primeira mercadoria uniformemente duplicável, a primeira linha de montagem - a produção em massa. Além disso, ela acendeu o desejo de imortalidade: todos queriam imprimir seus feitos, como se "a imortalidade fosse inerente à mágica repetição e extensão da imprensa” (MCLuhan, 1964, p. 200).

É interessante, ainda, ressaltar que a imprensa pôs um fim nos segredos dos alquimistas, tornando a ciência um empreendimento público. De acordo 
com Postman (1994), há uma estreita relação entre o crescimento da ciência e da prensa tipográfica, pois a imprensa anunciou o advento da ciência. Além disso, introduziu a idéia de mensuração de espaço e tempo.

De maneira gradual, novas concepções de conhecimento e inteligência foram tomando espaço, e, com elas, maior respeito pela razão e privacidade. Novas formas de discurso público foram sendo implementadas. A época tecnocrata (ou Idade Mecânica) foi a primeira a ter sua existência discutida em impresso, tanto que Tocqueville (1954) afirmava que a razão e a imprensa eram inseparáveis.

"As novas redes de comunicação $e$ informação digitais potencializam a liberação de uma multiplicidade de vozes, constituindo um novo poder

comunicativo real que pode se revelar de imprevisíveis maneiras"
Logo se compreendeu que o livro impresso havia criado uma crise de informação e que algo precisava ser feito para manter algum controle. Um meio foi a escola moderna, que tomou forma no século XVII. Segundo McLuhan (1964), houve várias razões para o crescimento da escola comum, mas nenhuma era mais óbvia que a necessidade de resposta às ansiedades e confusão causadas pela informação desenfreada. Por isso a invenção do currículo, para organizar, limitar a informação disponível. As escolas tornaram-se as primeiras burocracias seculares da tecnocracia, estruturas para legitimar parte do fluxo de informação e para desacreditar outras.

No uso da tecnologia, o homem é perpetuamente modificado por ela, mas, em compensação, sempre encontra novos meios de modificá-la. Utilizar ou perceber uma extensão de nós mesmos sob forma tecnológica implica necessariamente adotá-la. Ler uma página impressa é aceitar essas extensões de nós mesmos e sofrer o fechamento ou o deslocamento da percepção que automaticamente se segue (McLuhan, 1964, p.64).

\section{A Mídia Digital Escrita e sua Revolução}

As novas redes de comunicação e informação digitais potencializam a liberação de uma multiplicidade de vozes, constituindo um novo poder comunicativo real que pode se revelar de imprevisíveis maneiras (Lévy, 1995, p. 35).

Vivemos uma época inimaginável para gerações anteriores, para as quais, na história da civilização, há uma grande ruptura. Com a mídia digital, mudamos nossos fazeres, a noção tradicional de tempo e espaço, modo de pensar e relações. As transformações se seguem numa velocidade vertiginosa, e o ser humano nem sempre parece acompanhar todas elas, nem cognitiva nem emocionalmente.
O mundo eletrônico e os meios tradicionais de comunicação antecipam essa Revolução. Porém, esses meios, segundo Rolnik e Guattari (2000), tendem à subjetividade passiva, uma hegemonização do imaginário social e da subjetividade, entrando de acordo com McLuhan e Adorno. Já na mídia digital, o estabelecimento de uma hegemonia é praticamente impossível.

Cândido (2000) propõe uma analogia que expressa essa Revolução, onde a antiga praça pública estaria transformando-se em praça virtual planetária. Não é mais necessário um espaço físico em comum para os encontros. A Revolução é percebida nas formas de produção, distribuição e consumo da informação e do conhecimento. Isso retrata uma ruptura com as principais mercadorias e lógicas da sociedade industrial.

Nessa revolução, comparada a um dilúvio (Lévy, 1995), exige-se dos indivíduos contemporâneos a rápida inovação; quem não se renova, se estagna e corre o risco da exclusão. Isso provoca alterações subjetivas muito significativas; sempre se tem a sensação de estar "perdendo" algo, de estar sempre correndo atrás de um tempo que já se foi. Hoje, o acúmulo de informação não é a questão, e, sim, a renovação, a reciclagem.

Cândido (2000) aponta para as novas máquinas e redes de comunicação e interação digitais que disponibilizam grandes recursos no sentido de apropriação e da evolução cultural do coletivo humano. O computador em rede evoluiu para tornar-se o principal centro de informação e cultura e o maior meio de comunicação. Sua característica fundamental é a desterritorialização, além de concentrar em si os tradicionais meios de comunicação, como a escrita, apesar de transformada.

As construções subjetivas, nessa realidade, são desestabilizadoras em relação a toda uma lógica ordenada vigente, o que provoca a preocupação daqueles mais reticentes em relação a essa onda digital. Para Guattari (2000), é um momento em que a natureza explosiva e caótica do crescimento das telecomunicações provoca os contatos transversais. É uma inundação de signos.

Postman (1994) apresenta um ponto de vista mais temeroso sobre essa Revolução, mas também faz uma reflexão importante sobre a necessidade imprescindível de pensar e contestar as tecnologias em todos os ângulos, alertando que a tecnologia pode ser “amiga” e "inimiga”.

Para esse autor, toda essa Revolução pode criar uma cultura sem base moral, pois mina certos processos mentais e relações sociais e altera as 
estruturas sobre as quais pensamos e agimos. Exemplifica isso através das terminologias usadas na nossa linguagem em relação à máquina (“programar-se”, “vírus no computador”, “cérebro como disco rígido"), como sendo influência do que denomina Tecnopólio ${ }^{5}$.

Além disso, Postman (2000) enfatiza sua preocupação sobre o fato de a vida das pessoas ser mudada pela tecnologia e esse fato ser encarado como algo natural. Acredita que tal fato possa levar a um tratamento das pessoas como se fossem máquinas, devido ao desenvolvimento tecnológico. Se for para pensar nessa direção, é inevitável lembrar-se de Charles Chaplin, que já previa o mesmo problema na Inglaterra industrializada, bem retratado no clássico "Tempos Modernos", ou no "Grande Imperador", onde, no final do discurso, ele exclama: "Não sois máquinas, homens é que sois!”. A angústia não é atual, e não é determinada pela mídia digital.

Fica clara a posição defensiva do autor a essas transformações, que fariam parte desse "abalo sísmico”(Postman, 1994). Ele, portanto, faz uma analogia ao estagnado, à terra, e não à água e ao dilúvio, como Guattari e Deleuze, que, por sua vez, sugerem flexibilidade e fluidez.

\section{Cibercultura}

A cibercultura forma-se da convergência entre o social e o tecnológico, sendo através da inclusão da socialidade na prática diária da tecnologia que ela adquire seus contornos mais nítidos (Lemos, p. 93, 2002).

Estamos numa época "pré-cibercultura”, num processo de subjetivação que já se delineia sob diversos aspectos. Lévy (1999) entende a cibercultura como o conjunto de técnicas, práticas, atitudes, modos de pensamento e valores que se desenvolvem com o crescimento do ciberespaço. A descentralização cultural é um dos pontos chaves desse processo, através da desterritorialização do acesso à informação, onde as redes digitais, como um rizoma, disseminam-se tranversalmente. A informação não é recebida através de "filtros" e de maneira ordenada, mas, sim, caoticamente, onde a lógica emissor-receptor não faz mais sentido.

Outro aspecto é a possibilidade do encontro, mostrando suas diversidades, dando vazão ao encontro dos corpos (que aqui, também, são reais), às afetações e à alteridade. É sempre um movimento contrário à homogeneização.

A emergência do ciberespaço ${ }^{6}$ representa, para a civilização humana, um acontecimento comparável ao ocorrido a partir da Revolução Industrial, ainda que seja um desdobramento (e não substituição), uma extensão e aprofundamento desta.

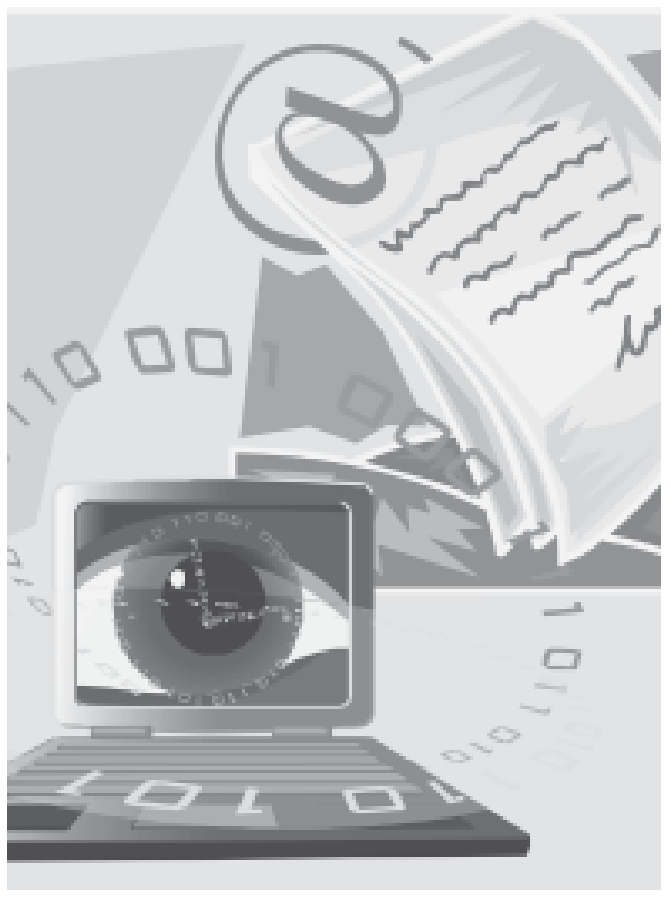

"A cibercultura forma-se da convergência entre o social e o tecnológico, sendo através da inclusão da socialidade na prática diária da tecnologia que ela adquire seus contornos mais nítidos

\section{Lemos}

\section{Transversalização da Mídia Impressa e Digital: Implicações Culturais e Subjetivas}

Não existe a "misteriosa comunicação" do passado com o presente, a não ser que aquele continue a atuar diretamente neste? Ou, em outras palavras, quando se transforma a situação, o que continua a influir é apenas o que, na situação nova, restou da anterior (...). O passado atua no presente e pode ser uma força determinante da ação, mas isso só ocorre quando forças do passado continuam no presente (Leite, 1969, pp. 328-329).

A mídia digital e impressa se transversalizam, não é possível pensá-las separadamente. Ambas surgem em épocas diferentes, o que não significa que uma exclua a outra, e, sim, que são re-significadas.

Lévy (1995) apresenta três formas pelas quais a humanidade organizou suas tecnologias de comunicação: da oralidade, escrita e informática. A oralidade primária, presente nas antigas civilizações, era o meio de comunicação e “armazenamento" cultural. Como Lévy (1995) bem compara: quando morria um ancião, uma biblioteca se queimava. Era uma cultura de repetição. A entrada da escrita nessas culturas condicionou uma série de mudanças culturais e
5 Postman (1994) considera o Tecnopólio como a redenção das pessoas à tecnologia, onde este seria o responsável por "alterar a estrutura de nossos interesses: as coisas sobre as quais pensamos. Alteram o caráter verdade, política, privacidade, etc" (Postman, 1994, p. 57).

6 O ciberespaço, segundo Lévy (1995), especifica não apenas a infra-estrutura material da comunicação digital mas também o universo oceânico de informações que ela abriga, assim como os seres humanos que navegam e alimentam esse universo. 
subjetivas, não só em relação à passagem de informação mas, principalmente, pelo modo como as pessoas passavam a se comunicar e a se entender também a partir da escrita.

Houve, nas duas revoluções, preocupações de que a nova invenção fosse desatualizar e/ou extinguir um meio mais antigo. Porém, para McLuhan (1969), um novo meio nunca se soma a um velho, nem deixa o velho em paz; ele nunca cessa de oprimir os velhos meios, até que encontre neles novas configurações e posições. Assim, a hibridação, proposta por McLuhan (1964), tem condições de acontecer a partir do encontro e afetação dos meios, criando a forma nova e a libertação do entorpecimento desses meios. É uma reinvenção.

McLuhan (1964) considera que todas as uniões híbridas geram liberação de energia e mudança, e cita a hibridação entre as culturas orais e letradas como maior representante disso: provocaram recomposições nos papéis e cenários sociais, borraram suas fronteiras, mas não apagaram sua existência. Isso explica o fato de a cultura existir num continuum, não no sentido linear, mas no sentido de interação incessante de tradição e mudança e de afetações com o outro (confirmando as conceitualizações contemporâneas de cultura).

A partir disto, talvez seja mais interessante pensar não em proporções de mudanças radicais, gigantescas, como propõe Postman, mas, sim, de transformações na realidade micro, nos agenciamentos dessa Revolução.

Lévy (1995) entende as transformações e implicações culturais da mídia digital a partir de uma mudança do vertical ao horizontal, ou seja, do "estoque" ao fluxo, sendo que o que acontece é a circulação de produtos, conhecimentos e seres humanos, e nunca sua estagnação. A própria noção de Identidade é alterada: não é vista apenas como um depósito, mas, sim, como sistema ativo de relações e metamorfoses. Outra transformação é o processo da heteronomia à autonomia, que, necessariamente, vem acompanhado de um processo de desenraizamento; há um abalo na lógica de hierarquização, através de um processo circular. Não impera mais a lógica da passagem da informação "um-todos" e, sim, "todos-todos" (Lemos, 2002). Essas mudanças do "micro” são exemplos que potencializam novas formas de saber, novas formas de se estar junto e de ser si mesmo.

Isso quer dizer que, com a transformação das tecnologias, o ser humano pode ressignificar-se através da interação “maquínica” de vários meios de comunicação tradicionais e particulares, ou seja, pela transversalização de tecnologias. Porém, isso provoca a desestabilização, logo, a "saudade" do mundo estabilizado.

Postman (1994) explicita isso na analogia do sistema de crença de uma cultura usuária de ferramentas com um novo baralho de cartas: sabe-se o que vem depois de certa carta, há uma seqüência. É um mundo compreensível. Já a Era Digital seria uma cultura parecida com um "baralho de cartas embaralhadas, produzida pelo caos da informação" (Postman, 1994, p.69). Isso porque o mundo nunca se confrontou com o excesso de informação, que levaria a um "colapso da tranqüilidade psíquica e do propósito social”. (Postman, 1994, p.63).

Sobre esse "excesso de informação", Cândido (2003) faz uma analogia a partir do projeto da biblioteca de Alexandria do antigo Egito. Ele remete esse desejo do "armazenamento do conhecimento” do passado a uma atualização, denominando o ciberespaço como uma Alexandria digital atual. Só que este não tem um território definido, tem o acesso ilimitado.

O textos impressos e digital têm muitas diferenças entre si, sendo operados em uma dimensão distinta, assim como acontece numa biblioteca real e virtual. McLuhan (1964) fala de meios frios e quentes, sendo que, quanto maior a possibilidade de interação com o meio, mais frio é esse meio. O texto digital evolui simultaneamente com quem o produz, é meio frio, interativo. Ele está sempre se reconstruindo, fazendo novas dobras, renovandose com seu autor. Mas, se isso passa uma idéia de uma nova dinâmica interativa, também pode passar a idéia de transitoriedade.

Postman (1994), Cândido (2000) e Guattari (1992) usam várias metáforas associando essa realidade digital à água: dilúvio, ondas, oceânico. Isso pode remeter à idéia de transitoriedade (de identidades, conhecimentos, relações afetivas, etc.), mas também a uma certa permanência, figurada pela água em si, mas que não sustenta a noção de "núcleo" e "essência”. Remete, sim, a movimento e às mudanças aí implicadas. Além disso, uma onda, um dilúvio, nunca vem de razões simples e deterministas. O desafio é (re)aprender a navegar. Como bem afirma Cândido (2003, s.p.): “É preciso reinventar o próprio pensamento, porque o certo é que o dilúvio não vai parar. O perigo de se afogar é real. O perigo de ficar à deriva é real. Mas não existe navegação sem perigos.”

Hall (2000) analisa esse sujeito na pósmodernidade, agente nesse dilúvio. Acredita que haja perda de um sentido estável de si, uma descentração do sujeito, uma crise de identidade. 
Nas muitas identidades pós-modernas, existe a constância da mudança: renovação incessante para acompanhar a velocidade instaurada por uma nova lógica do tempo e de mercado. Para Hall (2000), isso pode significar que cada um pode desfazer-se de certas características pela nova aparência e imagem do amanhã. A partir disso, pode-se pensar numa analogia das subjetividades com os meios de comunicação: na digital, o tema central é renovação, flexibilidade, remetendo a configurações identitárias semelhantes, enquanto que a mídia impressa, que tem como marco a "fixidez", sugere identidades permanentes como eram as identidades modernas. O impresso é visível, concreto, ao alcance da mão e olhos; é a extensão destes. Portanto, há esse movimento de subjetivação entre o estável e o instável, o visível e o invisível, da ordem e do caos, lados de uma mesma moeda que são, cada vez, menos separáveis. McLuhan (1964) já falava a respeito de uma ansiedade, nos anos 60, na "Era da Eletrônica", que considerava ser a "Idade da Angústia", destinada a cumprir as tarefas de hoje com as ferramentas de ontem. O impasse não mudou.

Justamente pelo fato de a construção da subjetividade se fazer no coletivo, mas ser singularizada, aparecem diferentes manifestações para o mesmo fenômeno, como as de Lévy e Postman. Enquanto, de um lado, surge uma movimentação produtiva (no sentido de potência) em relação a essas novas realizações subjetivas com os meios de comunicação, de outro, há um profundo anseio em como isso pode levar ao caos indesejado. É importante ressaltar que a noção de "caos" é vista de maneira diferente, nessas duas concepções, sendo que a primeira entende o caos como possibilidade de criação, o “desorganizar para organizar”, enquanto que o segundo percebe o caos como fuga total de controle.

O determinismo tecnológico tem a concepção da segunda visão de caos. Este implica uma percepção simplificada e mecânica das relações entre a subjetividade e a tecnologia, pois desconhece o fato de que

a máquina é, em si mesmo, um acontecimento subjetivo. As máquinas são ferramentas, instrumentos, mas que, em seus processos de invenção e uso, correspondem aos desejos e ficções humanas. A máquina é subjetiva antes de ser objetiva (Guattari, 2000, p.35).

Portanto, não é possível a dicotomia Homem x Máquina. Existe uma implicação na qual a subjetividade se transforma a partir da invenção de um dispositivo, na direção e dimensão próprias do dispositivo tecnológico em questão.
Nessa concepção, é preciso sair da noção de que subjetividade seja algo associado à esfera psi. Não se trata nem de esferas nem de limitação a alguma área do conhecimento.

De acordo com Cândido (2000), a subjetividade contemporânea é transversalizada por dois grandes movimentos: de um lado, um embrutecimento massivo da subjetividade pelos meios de comunicação de massa e, de outro, as revoluções moleculares da subjetividade pelas novas tecnologias. Esse segundo movimento seria uma possibilidade de re-singularização, da invenção de novos devires. Trata-se de transformação, e não substituição. Os livros, por exemplo, continuam a ser impressos, mas é irreversível sua transformação: na Era Mecânica, obedeciam a uma lógica de difusão; na digital, é a lógica de mundialização.

Tal evolução "maquínica” não pode ser julgada nem positivamente nem negativamente, como afirma Guattari (2000):

Não se trata de categorizações em "bom/ruim”. É então preferível pensar se se objetiva, reifica, se cientificiza a subjetividade ou se se tenta apreendêla em sua dimensão de criatividade processual. Tudo depende de como for sua articulação com os agenciamentos coletivos de enunciação. O melhor é a criação, a invenção de novos universos de referência; o pior é a mass-midialização embrutecedora.

(Guattari; Rolnik, 2000, p. 24)

Cândido (2000) complementa essa idéia ao afirmar a possibilidade de as evoluções tecnológicas ajudarem a sair de um período opressivo para entrar numa outra era além daquela caracterizada pelos meios de comunicação em massa, que, por sua vez, seria caracterizada por uma reapropriação e uma re-singularização da utilização dos meios de comunicação. São, enfim, movimentos que entendem esse dilúvio como a maneira positiva para a construção de novos tipos de barcas - não apenas uma, mas várias delas.

\section{Conclusão}

A única finalidade aceitável das atividades humanas é a produção de uma subjetividade que enriqueça de modo contínuo sua relação com o mundo (Guattari, 1992, p.33).

Este trabalho transitou entre vários fios, onde as várias interfaces da escrita digital, impressa, e suas implicações na cultura e subjetividade foram configurando diferentes desenhos.

Foi possível perceber o quanto esse olhar transversal e móvel sobre as mutações da escrita se

\section{A única finalidade aceitável das atividades humanas é a produção de uma subjetividade que enriqueça de modo contínuo sua relação com o mundo}

Guattari 
expressa em modos de pensar, agir, entender o tempo e as relações, enfim, a cultura.

As preocupações da Era Digital revelam um modo de pensar análogo ao modo de operacionalizar as informações recebidas da rede. Revelam que culturas são afetadas pela sua existência, muitas vezes com uma velocidade que dizem não compactuar com a nossa evolução.

Há uma processualidade na mudança de lógica, onde se pensa a partir de tecnologias do passado e isso abarca os processos de subjetivação de nossa época. A passagem da lógica do papel para os bytes mostrou o quanto as mudanças, os processos de subjetivação, são reordenados a partir da transformação das percepções.

Porém, concluiu-se que não se trata de substituição do que foi produzido no passado; a questão é sua transformação; a processualidade não pára. A escrita, como meio, acompanha esse processo; pode ter outros formatos, outras possibilidades de leitura e produzir diferentes sentidos, enfim, ser reinventada.

Assim, nosso grande desafio é justamente este: a (re)invenção.

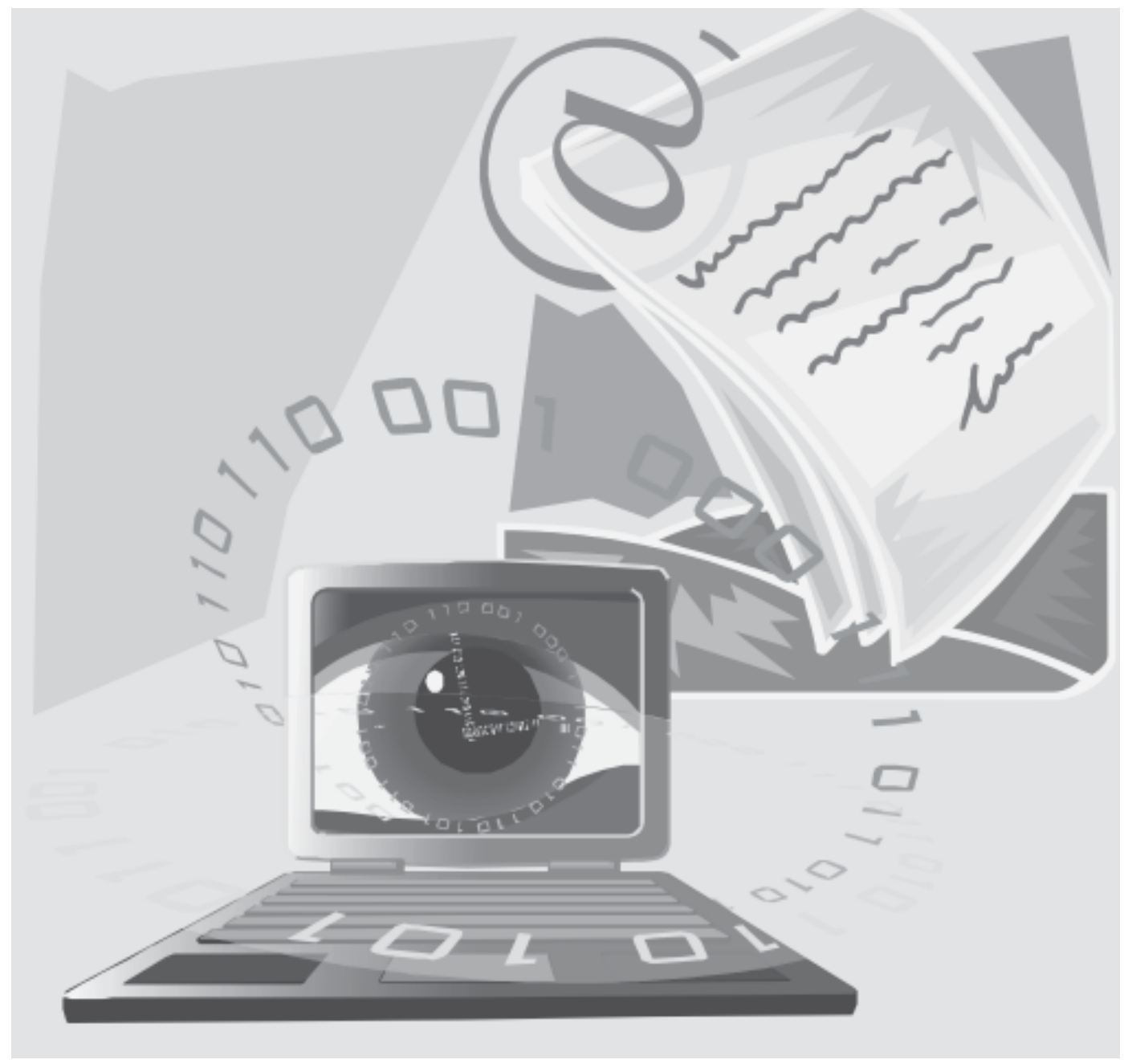


Transitando entre Folhas e Bytes

a Expressão da Mídia Impressa e da Mídia Digital na Cultura e na Produção de Subjetividades

Cristina Wulfhorst

Rua São Caetano, 785/404 Cep.:93010-000

São Leopoldo/RS

E-mail: Criswulf@yahoo.com.br

Recebido 07/04/04 Aprovado 25/08/04

AUGE, Marc. Hacia una Antropologia de los Mundos Contemporaneos. Barcelona: Gedisa, 1988.

BOUGNOX, Daniel. Introdução à Ciência da Informação e da Comunicação. Petrópolis: Vozes, 1994.

CAMPOS, Arnaldo. Breve Histórico do Livro. Rio de Janeiro: Mercado Aberto, 1994.

CANCLINI, N. G. Culturas Híbridas: Estrategias Para Entrar y Salir de la Modernidad. Barcelona: Editora Paidós, 2001.

CÂNDIDO, Celso. As Transformações da Subjetividade no Contexto das Tecnologias Intelectuais Contemporâneas. São Paulo: USP, 2003. Dissertação de Doutorado em Psicologia Social, Faculdade de Psicologia, Universidade de São Paulo, 2003.

DELEUZE, Gilles. Diferença e Repetição. São Paulo: Graal, 1988.

GUATTARI, Félix. Caosmose: um Novo Paradigma Estético. São Paulo: ed. 34, 1992

GUATTARI, Félix; ROLNIK, Suely. Micropolítica: Cartografias do Desejo. Petrópolis: Vozes, 2000.

HALL, Stuart. A Identidade Cultural na Pós-modernidade. $4^{\mathrm{a}} \mathrm{ed}$. Rio de Janeiro: Dp\&a, 2000.

LARAIA, Roque de Barros. Cultura: um Conceito Antropológico. Rio de Janeiro: Jorge Zahar Editora, 2002.
LEITE, Dante Moreira. O Caráter Nacional Brasileiro: História de uma Ideologia. São Paulo: Pioneira, 1969.

LEMOS, André. Cibercultura: Tecnologia e Vida Social Contemporânea. Porto Alegre: Editora Sulina, 2002

LÉVY, Pierre. Cibercultura. São Paulo: Companhia das Letras, 1995. LIPOVETSKY,Gilles. AEra da Razão. Lisboa: Relógio d’ Água, 1983.

MATURANA, Humberto; VARELA, Francisco. A Árvore do Conhecimento. Campinas: EditoriaPsy, 1987.

MEAD, Margaret. Culture and Commitment: a Study of the Generation Gap. The American Museum Natural History: Garden City, 1970.

MCLUHAN, Marshall. Os Meios de Comunicação Como Extensões do Homem. Editora Cultrix, São Paulo:1964.

Os Meios São as Massa-gens. $2^{\mathrm{a}} \mathrm{ed}$. Rio de Janeiro: Editora Record, 1969.

POSTMAN, Neil. Tecnopólio: a Rendição da Cultura à Tecnologia São Paulo: Nobel, 1994.

SEMPRINI, Andrea. Multiculturalismo. Bauru-SP: EDUSC, 1999.

TOCQUEVILLE, Alexis de. Das Zeitalter der Gleicheit. Stuttgart: Alfred Kraner, 1954.
Referências 